\title{
Comparative study of marketing efficiency of seaweed Glacillaria Sp and Spinosum Sp
}

\author{
1Megawati, 2Didi Rukmana, 3Hamzah, 4Sitti Nurani Sirajuddin
}

1Agribusiness Study Program, Graduate School Hasanuddin University, Makassar, 90245, Indonesia

2 Agribusiness Study Program, Graduate School Hasanuddin University , Makassar, 90245, Indonesia

3Agribusiness Study Program, Graduate School Hasanuddin University, Makassar, 90245, Indonesia

Agribusiness Study Program, Graduate School Hasanuddin University, Makassar, 90245, Indonesia

Correspondence Author: Megawati, 1Agribusiness Study Program, Graduate School Hasanuddin University, Makassar, 90245, Indonesia Email: megawati@pasca.unhas.ac.id

Received date: 20 May 2019, Accepted date: 20 July 2019, Online date: 28 July 2019

Copyright: (C) 2019 Megawati et al., This is an open-access article distributed under the terms of the Creative Commons Attribution License, which permits unrestricted use, distribution, and reproduction in any medium, provided the original author and source are credited.

\begin{abstract}
One of the centers of seaweed cultivation in South Sulawesi province is Sinjai regency. Based on the data on the export value approach and the production value of seaweed is known to have margin in the price of export seaweed in Indonesia and there is a price fluctuations at the farmer level. It is therefore assessed necessary to know its influence on seaweed marketing through a marketing analysis approach. The purpose of the study is to know the marketing efficiency of dried seaweed (Eucheuma Spinosum Sp and Glacillaria Sp) in Sinjai County. This study was conducted in Sinjai County, South Sulawesi Province during February to April 2019. The research respondent consisted of a farmer of respondents who amounted to 60 people and 6 marketing institutions. Withdrawal of respondents was done using the purposive sampling method. The analysis of the data on this research consists of a channel analysis approach and marketing institutes, analysis of marketing functions, and analysis of market behavior in a descriptive analysis. In addition, quantitative analysis was conducted through the value of margin marketing approach, farmer's share and marketing efficiency analysis. The results of the margin analysis show that channel I has the smallest marketing margin value of Rp 5.500 for the type Glacillaria and Rp 4.200 for the type of Spinosum per kilogram of dried seaweed. The highest share analysis is $35.29 \%$ for Glacillaria and $54,34 \%$ of Spinosum. From these results shows that farms are more efficient than seaweed market in coastal areas, which is reflected in the marketing margin and farmer ' share.
\end{abstract}

Keywords: seaweed, efficiency marketing, marketing analysis

\section{INTRODUCTION}

Seaweed (Seaweed) is one of the fishery commodities that is economically valuable and has extensive global access and bright business prospects in the national and international markets. Seaweed is still widely exported in the form of raw material is dried seaweed. A total of $85.5 \%$ of dried seaweed raw material production was exported to China, the European Union, and the Philippines [6]. The fact that often faced by seaweed farmers in Sinjai district is a rapid development on the production side but the price at the cultivated level is very low. Some factors allegedly affect the low quality of the product, the length of the distribution channel, the high cost of transportation, the uncertainty of price and the disharmony of the relationship between farmers and traders, and the lack of information Seaweed marketing conducted by the field extension officers so that farmers can not take part in the pricing of seaweed.

The seaweeds are belonging to algae group. Biologically, based on their nutritional value and chemical composition, the seaweeds are classified as Chlorophyta (green algae), Rhodophyta (red algae) and Phaeophyta (brown algae) [5,10]. In general, there were reports on the antioxidant properties of the brown, red and green algae [4,12] while other researcher discovered antibacterial activities of some seaweeds extracts against pathogen of general health interest [4,7], antifungal [8] and antiinflammatory [1] activities. Some seaweed cultivation in Sinjai Regency has formed a group of farmers to facilitate the management of its business activities. The presence of a farmer group was made to facilitate the activity of seaweed marketing in 
Sinjai regency. Based on information obtained even though the farmer group is already present in the midst of society but there are still farmers do choose to manage seaweed cultivation efforts individually. The market holds a very important control in the business system, and unfortunately the marketing problems to date still embrace the free market system. There is no protection for farmers in terms of marketing results. The birth of Law No. 7 of 2016 on the protection and empowerment of fishermen, fish farmers, and salt farmer, has not touched up to the marketing aspect. So there is no bargain price for farmers [11]. The length of the marketing chain has caused seaweed prices to be depressed at unfavorable price levels [2,3]. The farmer group's presence has not yet support the whole seaweed farmer in Sinjai County. There are still many farmers selling their lawns directly to the collecting merchant. This automatically raises the difference in income gained by farmers belonging to the farmer group with farmers who manage their business individually. Therefore, the research aims to analyze the efficiency of seaweed marketing in Sinjai County.

\section{MATERIAL AND METHODS}

This research was conducted in Sinjai County, South Sulawesi Province. The location of this research was chosen intentionally (purposive sampling) with the consideration that this region has a great potential for the development of seaweed cultivation. This study will be conducted in January to April 2019. Determination of the number of samples, determination of the respondents farmers performed purposive sampling, namely intentionally but with the consideration of certain characteristics. In this study respondents who were taken into a population were the seaweed farmers in Sinjai district that belonged to the farmer group and the seaweed farmer who did not join the farmer group and did not do the activity Facilitated by the group. Some of the characteristics of seaweed farmers as consideration is seen from the average production volume every time harvest and experience seaweed cultivation business. The population of seaweed farmers in Sinjai Regency was 593 people, and in this study took 60 farmer respondents, when the population reached 100 people then the number of samples was at least $10 \%-15 \%$ of the amount The population [7,13]. Therefore, the respondents who took the farmer consists of 30 who did sales of the group seaweed that originated from the farmer groups Tajollo Lagoari, Mina Bahari, Mattiro Laut, Sipakatuo, Pattiro Deceng, Crown Queen, Kris Muda, Reso Temmangingi, Sinar Jaya, grouper, Lembang ' E, pumice, rays of the sea, Mayana, Bone Bay, Aisyah, Kanalo, sea flowers, hopes together, Panambe, and Ajra Hidayat and 30 farmers who do sales of seaweed individually. The withdrawal of farmers who manage marketing activities through farmer groups is conducted based on directions from the field extension of Sinjai County. Using marketing efficiency analysis.

\section{RESULTS AND DISCUSSION}

At the determination of seaweed marketing efficiency in Sinjai District do a standardization of dried seaweed quality on each marketing channel to compare the efficiency value of each-component channel - The calculated component In determining the value of marketing efficiency obtained from the results of calculations on the quality conditions of dried seaweed with a moisture content of $35 \%$.

Table 1: Marketing efficiency of dried seaweed in Sinjai County

\begin{tabular}{|l|c|c|c|c|}
\hline $\begin{array}{c}\text { Channels } \\
\text { Marketing }\end{array}$ & $\begin{array}{l}\text { Prices on } \\
\text { farmers } \\
(\mathrm{Rp} / \mathrm{Kg})\end{array}$ & $\begin{array}{c}\text { Prices on exporters } \\
(\mathrm{Rp} / \mathrm{Kg})\end{array}$ & Marketing margin & $\begin{array}{c}\text { Farmer's Share } \\
(\%)\end{array}$ \\
\hline Channels I : & 3.000 & 8.500 & 5.500 & 35,29 \\
\hline Glacillaria $S p$ & 5.000 & 9.200 & 4.200 & 54,34 \\
\hline Spinosum Sp & & 8.800 & 6.100 & 30,68 \\
\hline Channels II : & 2.700 & 10.000 & 5.200 & 48 \\
\hline Glacillaria $S p$ & 4.800 & & & 30 \\
\hline Spinosum $S p$ & & 9.000 & & \\
\hline Channels III : & 2.700 & & & \\
\hline Glacillaria $S p$ & & & & \\
\hline
\end{tabular}

Primary: Data Source 2019, (processed)

Table 1 presents data on the value of marketing efficiency on every channel that is formed with the condition of dried seaweed products. Be based on Such data can be seen from the value of margin and the farmer's share then channel I relatively more efficient in comparing two other types of channels for the type Glacillaria and Spinosum,With a margin value of Rp 5,500.00 for the type Glacillaria and Rp 4,200.00 type Spinosum and Farmer'share of 35.29\% type Glacillaria and 54\% Spinosum type. 


\section{CONCLUSION}

In the results of marketing efficiency analysis shows that there is a difference in price, Farmer's Share and the margin obtained by each perpetrator in the marketing of seaweed in Sinjai district. Therefore, it is necessary to do socialization or training about the importance of the farmer group's role in information about seaweed quality standardization good for export. Raising the quality standards of seaweed in particular through the decline in water content levels can be done as an effort to increase selling price at the farmer level TA increase consumer satisfaction in this case exporters due to fulfilled export standardization on Seaweed Marketing in Sinjai County.

\section{REFERENCES}

[1] Abdel-Raouf, N., I.B.M. Ibraheem, M.S. Abdel-Hameed and K.N. El-Yamany, 2008. Evalution of antibacterial, antifungal and antiviral activities of ten marine macroalgae from Red Sea Egypt. Egyptian Journal of Biotechnology, 29: 157-172.

[2] Ariwijaya, H, dan J.Z. Djamalang, 2008. Faktor-Faktor yang Mempengaruhi Produksi dan Pendapatan Usaha Tani Rumput Laut Kappaphycus alvarezii di Kecamatan Liang Kabupaten Banggai Kepulauan.Jurnal BPPT, 2 (5): 2-13.

[3] Aziz, Y.H. 2011. Optimasi pengelolaan Sumber Daya Rumput laut di Wilayah Pesisir Kabupaten Bantaeng Propinsi Sulawesi Selatan. Disertasi. Sekolah Pascasarjana Institut Pertanian Bogor. 163.

[4] Chew, Y.L., Y.Y. Lim, M. Omar, K.S. Khoo, 2008. Antioxidant activity of three edible seaweeds from two areas in South East Asia. LWT - Food Science and Technology, 41(6): 1067-1072.

[5] Dawczynski, C., R. Schubert, G. Jahreis, 2007. Amino acids, fatty acids, a dietary fibre in edible seaweed products. Food Chemistry, 103: 891-899.

[6] Dinas Perikanan dan Kelautan Kabupaten Sinjai, 2018. Kabupaten Sinjai Dalam Angka 2012-2018.Sinjai. 548 .

[7] Hanafiah dan Saefuddin, 2010. Tataniaga Hasil Perikanan. Universitas Indonesia. Jakarta.

[8] Nikhashemi S.R and Paim H.L, 2014. Driving Forces of Hypermarket's Customer Loyalty: An Emperical study in Malaysia. Journals American-Eurasian Network For Scientific Information (AENSI). 8 (3) 377-386 .

[9] Sabirin F, Kazi. J. A, Ibrahim. I. S, 2015. Screening of Seaweeds Potential Against Oral Infections. Journals AmericanEurasian Network For Scientific Information (AENSI). 11(15) 1-6.

[10] Saidani, K., F. Bedjou, F. Benabdesselam, N. Touati, 2012. Antifungal activity of methanolic extracts of four Algerian marine algae species. African Journal of Biotechnology, 11(39): 9496-9500.

[11] Sitti Nurani Sirajuddin, et al., 2013. Comparative Advantage Analysis on Self Dependent and Business Partnership of Dairy Farmers.Global Veterinaria, 10(2): 165-170.

[12] Soltani, S., M.A. Ebrahimzadeh, R. Khoshrooei, Z. Rahmani, 2012. Antibacterial and antihemolytic activities of Enteromorpha intestinalis in Caspian Sea Coast, Iran. Journal of Medicinal Plants Research, 6(3): 530-533.

[13] Sugiono, 2012. Metode Penelitian Kualitatif Kuantitatif dan R\&D. Bandung: Alfabeta. 